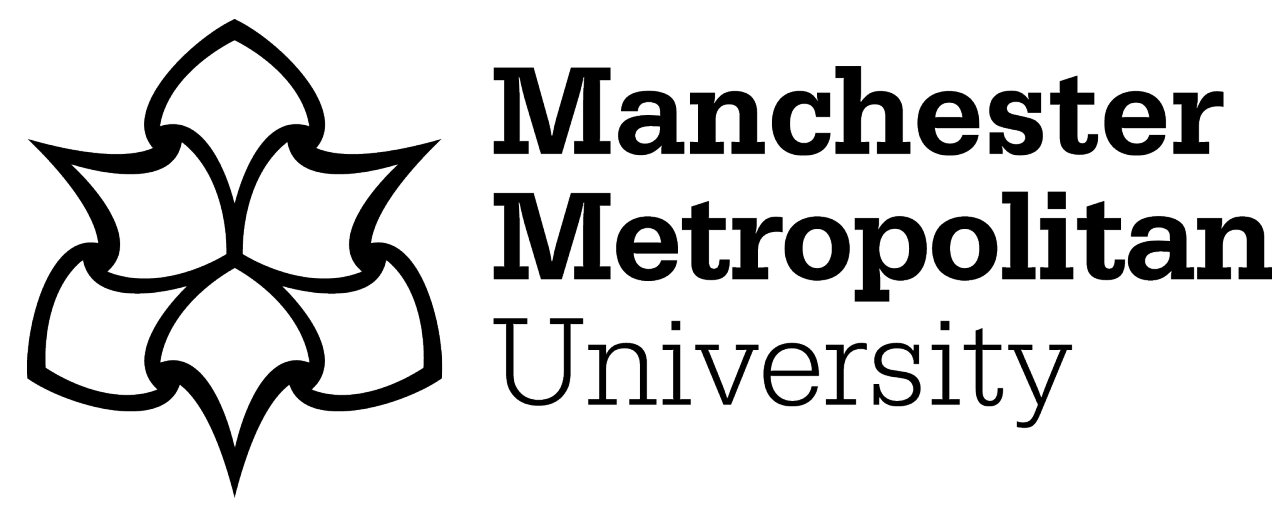

Flores-Rentería, D, Curiel Yuste, J, Rincón, A, Brearley, FQ, García-Gil, JC and Valladares, $F$ (2015) Habitat Fragmentation can Modulate Drought Effects on the Plant-soil-microbial System in Mediterranean Holm Oak (Quercus ilex) Forests. Microbial Ecology, 69 (4). pp. 798-812. ISSN 0095-3628

Downloaded from: https://e-space.mmu.ac.uk/583620/

DOI: https://doi.org/10.1007/s00248-015-0584-9

Please cite the published version 


\section{Habitat fragmentation can modulate drought effects on the plant-soil-microbial system in Mediterranean Holm oak (Quercus ilex) forests}

Dulce Flores-Rentería ${ }^{1}$, Jorge Curiel Yuste ${ }^{1}$, Ana Rincón ${ }^{2}$, Francis Q. Brearley ${ }^{3}$, Juan Carlos García-Gil ${ }^{4}$, Fernando Valladares ${ }^{1}$

${ }^{1}$ Department of Biogeography and Global Change, Museo Nacional de Ciencias Naturales (MNCN), Spanish Scientific Council (CSIC). Serrano 115bis, 28006. Madrid, Spain.

${ }^{2}$ Department of Plant Protection, Instituto de Ciencias Agrarias, ICA-CSIC. Serrano 115bis, 28006. Madrid, Spain.

${ }^{3}$ School of Science and the Environment, Manchester Metropolitan University, Chester Street, Manchester, M1 5GD, UK.

${ }^{4}$ Department of Environmental Contamination, ICA-CSIC. Serrano 115bis, 28006. Madrid, Spain.

Corresponding Author: Dulce Flores-Rentería, Department of Biogeography and Global Change, MNCN-CSIC, Serrano 115, E-28006. Madrid, Spain. Tel: +34 917452500 ext 980801; Fax: +34 915640800; E-mail: yaahid@mncn.csic.es 


\begin{abstract}
Ecological transformations derived from habitat fragmentation have led to increased threats to above-ground biodiversity. However, the impacts of forest fragmentation on soils and their microbial communities are not well understood. We examined the effects of contrasting fragment sizes on the structure and functioning of soil microbial communities from Holm oak forest patches in two bioclimatically different regions of Spain. We used a microcosm approach to simulate the annual summer drought cycle and first autumn rainfall (rewetting), evaluating the functional response of a plant-soil-microbial system. Forest fragment size had a significant effect on physicochemical characteristics and microbial functioning of soils, although the diversity and structure of microbial communities were not affected. The response of our plant-soil-microbial systems to drought was strongly modulated by the bioclimatic conditions and the fragment size from where the soils were obtained. Decreasing fragment size modulated the effects of drought by improving local environmental conditions with higher water and nutrient availability. However this modulation was stronger for plant-soil-microbial systems built with soils from the northern region (colder and wetter) than for those built with soils from the southern region (warmer and drier) suggesting that the responsiveness of the soil-plant-microbial system to habitat fragmentation was strongly dependent on both the physicochemical characteristics of soils and the historical adaptation of soil microbial communities to specific bioclimatic conditions. This interaction challenges our understanding of future global change scenarios in Mediterranean ecosystems involving drier conditions and increased frequency of forest fragmentation.
\end{abstract}

Keywords: microorganisms, soil respiration, habitat fragmentation, drought, rewetting. 


\section{Introduction}

The impacts of global change disturbances are directly responsible for increased rates of biodiversity loss, which are altering the functioning of ecosystems and affecting important ecosystem services [1]. In the Mediterranean basin, forest fragmentation, resource overexploitation and poor management are the main drivers of forest degradation, and their impacts are expected to be aggravated by climate change [2]. Habitat fragmentation negatively affects population size and/or diversity of organisms in large habitats (reviewed by $[3,4]$ ), although it is still not clear if it has a consistent effect on biodiversity loss [5], since neutral (e.g. microorganisms [6]) or even positive effects $[7,8]$ have also been reported. It is well known that consequences of habitat fragmentation are strongly dependent upon the size of the remaining area $[9,10]$, because of the complex processes related to edge effects [10], and resource constraints in smaller fragments [11]. Most Mediterranean ecosystems have historically suffered major transitions involving fragmentation due to agricultural practices that transform the landscape dominated by forest and shrublands into isolated patches [12], in a process that is expected to become more frequent over the next century [13]. Evidence of fragmentation effects in Mediterranean ecosystems has been reported for a range of different organisms such as birds, butterflies, plants and microorganisms, and includes the disruption of biotic interactions such as pollination, seed dispersal and herbivory [2, 8, 14-16].

The global climate is expected to change rapidly and deeply over the next century [1]. Particularly in the Mediterranean basin, an increase in temperature of $1.8^{\circ} \mathrm{C}$ is predicted for the next 40 years, coupled with a reduction in rainfall frequency of $5-10 \%$ with more intense droughts [1]. The functioning of Mediterranean ecosystems is largely governed by the soil water regime $[17,18]$ and reductions in soil water are very likely to cause a concomitant reduction in carbon and water fluxes [18-20]. The increased intensity of droughts in recent decades has led to the reduction of tree productivity in the Mediterranean Basin [18, 21], and to forest decline in some areas [22]. These global changes directly affect plant communities, but also simultaneously and interactively affect the 
associated belowground microorganisms [23]. The changes in precipitation patterns can also affect soil nutrients and carbon cycling by impacting upon the activity of microbial communities [24], although a considerable debate about how water stress affects soil microbial communities and their overall activity still exists $[23,25,26]$. Relative shifts in soil microbial communities depends on their different inherent resistances to drought [27], with soil bacterial community generally considered more sensitive than the fungal community $[23-25,28,29]$.

Soils and their microorganisms are essential for the performance and regulation of global biogeochemical cycles [30-32]; their activity is controlled by both biotic and abiotic factors such as quantity and quality of litter inputs, temperature, and moisture [23, 28, 29, 33-35]. Changes in soil communities and the loss of soil biodiversity threaten the multifunctionality and sustainability of ecosystems, with negative impact on plant diversity and nutrient cycling and retention [36], whereas a more diverse microbial community could be associated with higher resistance to disturbance [37]. In parallel, microbial processes have been related to variations in ecosystem properties, such as tree productivity $[30,37,38]$.

Most studies of habitat fragmentation have focused on above-ground organisms, while only a few have addressed effects of fragmentation on soil physicochemical characteristics, functioning [16], or microbial structure [6]. In Mediterranean gypsic soils, Lázaro-Nogal et al. [16] found that the synergistic interaction between habitat fragmentation and habitat quality was negatively correlated with soil nutrients and enzymatic activity. Results of simulated fragmentation from Rantalainen et al. (reviewed in [6]) suggested that habitat fragmentation did not have a direct effect on soil microorganisms. However, the effects of habitat fragmentation on the plant-soil-microorganism system remain largely unknown and especially their interaction with drought. Our general objective was to study the impact of drought and rewetting on the structure and functioning of microbial communities in soils from two climatically different regions and from forest fragments of contrasting sizes in a microcosm experiment. To assess potential interactions between fragmentation and 
climate, we explored the physiological responses to drought of oak seedlings grown in soils from contrasting fragment sizes. First, we hypothesized that physicochemical characteristics of soils and their microbial biomass would differ in forest fragments of contrasting sizes. Second, we hypothesized that the functional response of the plant-soil-microbial system to climatic simulations (drought and rewetting) would be determined by the particular initial microbial communities and biogeochemical properties associated with the size of the fragment.

\section{Material and Methods}

\section{Soil provenance}

We selected three large (> 10 ha) and three small (<0.5 ha) Holm-oak (Quercus ilex L. ssp. ballota (Desf.) Samp; Fagaceae) forest fragments, resulting from the conversion to an agricultural landscape, located in two climatically different regions of central Spain (12 forest fragments in total). In the northern region (Lerma; $41^{\circ} 58^{\prime}-42^{\circ} 02^{\prime} \mathrm{N}, 03^{\circ} 45^{\prime}-03^{\circ} 52^{\prime} \mathrm{W}$; $930 \mathrm{~m}$ asl) the studied fragments were in an area of 1500 ha, they showed similar characteristics in spatial structure and vegetation, and were separated by at least $50 \mathrm{~m}$ to a maximum of $11 \mathrm{~km}$ (Online Resource 1). This region is characterized by $554 \mathrm{~mm}$ mean annual precipitation and $11^{\circ} \mathrm{C}$ mean annual temperature [39]. The dominant tree species is also Holm oak, with isolated Lusitanian oak Q. faginea and Spanish juniper Juniperus thurifera L. and understory shrubs typical of wetter and cooler supramediterranean localities (e.g. Cistus laurifolius L., Genista scorpius (L.) DC, Thymus zygis Loefl. ex L.; see $[8,14]$ for further details). In the southern region (Quintanar de la Orden; 39 $39^{\circ} 0^{\prime}-39^{\circ} 35^{\prime} \mathrm{N}, 02^{\circ} 47^{\prime}-02^{\circ} 59^{\prime} \mathrm{W} ; 870 \mathrm{~m}$ asl), the studied fragments were in an area of 1000 ha, they showed similar characteristics in spatial structure and vegetation, and were separated by at least $50 \mathrm{~m}$ to a maximum of $8 \mathrm{~km}$ (Online Resource 1). This region is characterized by $434 \mathrm{~mm}$ mean annual precipitation and $14{ }^{\circ} \mathrm{C}$ mean annual temperature [39]. The dominant tree is the Holm oak Q. ilex with the understory composed of 
shrubby Kermes oak Quercus coccifera L. and shrub species typical of xeric mesomediterranean localities (e.g. Asparagus acutifolius L., Cistus ladanifer L., Rhamnus alaternus L., Rhamnus lycioides Brot.; see $[14,15]$ for further details). Both sites are characterized by a pronounced summer drought period, usually lasting from July to September. The climatic characteristics of the two study regions are representative of the mesomediterranean and supramediterranean bioclimatic zones of the Iberian Peninsula, respectively [40]. The dominant soils are classified as Cambisols (calcics) [41], sandy loam texture, with $17 \%$ sand, $39 \%$ silt and $44 \%$ clay for the southern region and, $11 \%$ sand, $42 \%$ silt and $47 \%$ clay for the northern region. In both regions, the original forest is now highly fragmented due to land conversion for intensive cultivation of cereal crops, legumes, and some grapes $[14,15,42]$. Remnants of forests were left between crops and now are imbibed in the agricultural matrix, yet clearly differentiated. Trees within large fragments were homogeneously distributed with low tree density, while the small fragments consist of at least four trees and with a high tree density (authors personal observations).

\section{Soil sampling}

We selected four trees with basal area of $\sim 500-600 \mathrm{~cm}^{2}$ within each fragment and region with six fragments in each region, making 48 trees in total. Four soil samples were taken in four orientations under the canopy of each tree to a depth of $0-15 \mathrm{~cm}$, and combined to a single sample per tree. Soils were collected at the end of the dry season. Once in the laboratory, soils were sieved $(<2 \mathrm{~mm})$, and air-dried for two weeks. Acorns of $Q$. ilex were collected from the southern region.

Soil physicochemical characteristics and microbial biomass were measured in all replicates of each fragment size. Since the level of spatial heterogeneity of soils at very small spatial scales would have blurred functional differences among fragments of contrasting size, and due to practical limitations of the experiment, conditions were standardised by combining soils into composite samples of small and large fragment types from each bioclimatic region; thus we finally obtained a total of four 
treatments: two factors (region and fragment size) with two levels each (region: northern and southern; fragment size: large and small).

\section{Soil abiotic characteristics and microbial biomass}

Physicochemical soil characteristics and microbial biomass were determined on air-dried soils, for all 48 soil samples. Water holding capacity of soils was determined by soaking the samples in water for $2 \mathrm{~h}$ and then draining for $24 \mathrm{~h}$ in a humid environment. Soil aggregate stability was determined on $2 \mathrm{~mm}$ aggregates by a water-drop test [43] using at least 20 aggregates per replicate. Soil $\mathrm{pH}$ was determined in a water slurry $\left(1: 5 \mathrm{w} / \mathrm{v}\right.$ in $\left.\mathrm{H}_{2} \mathrm{O}\right)$; soil organic matter ( $\mathrm{SOM}$ ) was assessed by loss on ignition at $400{ }^{\circ} \mathrm{C}$ for 4 hours. Organic $\mathrm{N}$ was determined by the Kjeldahl method [44]. Available phosphorus was determined by the Burriel-Hernando extraction method [45], and $\mathrm{K}^{+}, \mathrm{Ca}^{2+}, \mathrm{Na}^{+}$and $\mathrm{Mg}^{2+}$ were extracted with ammonium acetate $(1 \mathrm{M}, \mathrm{pH}$ 7) and subsequently determined by inductively coupled plasma spectrometry (Optima 4300DV, Perkin-Elmer, Waltham, USA). Microbial biomass carbon was determined by the chloroform fumigation-extraction method modified by Gregorich et al.[46].

\section{Experimental design}

Two-litre pots were filled with a mixture of 5:1 soil:perlite (v:v). Holm oaks acorns from the southern region randomly selected were soaked in water for $24 \mathrm{~h}$ before planting. Pots were randomly arranged in the greenhouse $\left(25{ }^{\circ} \mathrm{C}\right.$ and $40 \%$ air humidity), and regularly watered to field capacity based on weight loss (between $35-45 \%$ soil water content). Other seedlings that eventually germinated were carefully removed from the pots. We established three experimental periods during the dry-rewetting simulation: 1) pre-drought with seedlings growing in well-watered pots for 80 days; 2) drought for 55 days with no water supply (the drought was terminated when seedlings started to die); and 3) two days after rewetting, aboveground biomass was harvested and pots were 
watered to field capacity. We then measured the water potential of the harvested seedlings. Intermediate non-intrusive measures were carried out as indicated below.

\section{Seedling growth and physiological variables}

Seedling height and diameter were recorded every fifteen days (seven seedlings for southern large and northern small fragments, and eight seedlings for southern small and northern large fragments; 30 in total). Physiological variables were recorded at the same time interval: stomatal conductance $(g \mathrm{~s})$ was measured with a leaf porometer SC-I (Decagon, Pullman, USA), during the period of maximal conductance (10:00-12:00 h). Predawn and midday maximum photochemical efficiency of photosystem II $(F v / F m)$ were measured with a portable pulse-modulated fluorometer FMS2 (Hansatech, Norfolk, UK), for which the leaves were previously held in the leaf clip holder for 30 min. Final Specific Leaf Area (SLA) was determined as leaf area (determined with an optical scanner) per gram dry mass. Final predawn stem water potentials $\left(\Psi_{\mathrm{PD}}\right)$ were determined with a Scholander pressure chamber [47].

\section{Soil microbial community activity and fingerprinting profiles}

Three pots per treatment were selected for collection of soil samples at pre-drought, drought and after rewetting (12 soil samples per condition; 36 in total), which were stored at $4{ }^{\circ} \mathrm{C}$ for a maximum of two weeks or $-20{ }^{\circ} \mathrm{C}$ for subsequent enzymatic and molecular analyses, respectively. The acid phosphatase activity (phosphoric monoester hydrolases, EC 3.1.3.2) assay was based on the detection of $p$-nitrophenol (PNP) released after $0.5 \mathrm{~g}$ of soil was incubated in $0.1 \mathrm{M}$ maleate buffer at $\mathrm{pH} 6.5$ $\left(37{ }^{\circ} \mathrm{C}, 90 \mathrm{~min}\right)$ with p-nitrophenyl phosphate disodium as substrate [48]. The urease activity (amidohydrolase, EC 3.5.1.5) assay was based on the detection of $\mathrm{NH}^{4+}$ released after $0.5 \mathrm{~g}$ of soil was incubated in $1 \mathrm{M}$ phosphate buffer at $\mathrm{pH} 7\left(30^{\circ} \mathrm{C}, 90 \mathrm{~min}\right)$ with $1 \mathrm{M}$ urea as a substrate [49]. 
Community structure of soil fungal and bacterial communities was assessed by the DNA community fingerprinting technique of denaturing gradient gel electrophoresis (DGGE). Soil DNA was extracted with the MoBio Powersoil DNA isolation kit (Solana Beach, USA), and yields assessed by electrophoresis at $80 \mathrm{~V}$ on a $1.2 \%$ agarose gel. For fungi, the internal transcribed spacer nrDNA region ITS-1 was PCR-amplified using the primer pair ITS1-F/ITS2 [50]. The universal primers 338F/518R were used for amplification of the bacterial 16S rRNA gene [51]. A GC clamp was added to the 5' end of forward fungal (ITS1-F) and bacterial (338F) primers to stabilize the melting behaviour of the DNA fragments [51]. PCRs were carried out on a PTC-200 Thermocycler (MJ Research, Massachusetts, USA), with $50 \mu \mathrm{l}$ of reaction mixture containing 10x $\mathrm{NH}_{4}$ reaction buffer, 2 and $1.5 \mathrm{mM} \mathrm{MgCl}_{2}$ (for fungi and bacteria, respectively), $0.2 \mathrm{mM}$ total dNTPs, $2.5 \mathrm{U}$ Taq (Bioline, London, UK), $1 \mu \mathrm{M}$ of each primer, $0.5 \mu \mathrm{l}$ of $10 \mathrm{mg} \mathrm{ml}^{-1}$ bovine serum albumin (BSA) and $50 \mathrm{ng}$ of template DNA, determined using a Nanodrop 2000c (Thermo Fisher Scientific, Wilmington, USA). PCR cycling parameters were: $94{ }^{\circ} \mathrm{C}$ for 5 min, followed by 35 cycles of $94{ }^{\circ} \mathrm{C}$ for $30 \mathrm{~s}, 55^{\circ} \mathrm{C}$ for 30 or $45 \mathrm{~s}$, and $72{ }^{\circ} \mathrm{C}$ for 30 or $45 \mathrm{~s}$, with a final extension at $72{ }^{\circ} \mathrm{C}$ for 5 or $10 \mathrm{~min}$ (for fungi and bacteria, respectively). Negative controls (with ultrapure water instead of DNA) were included in each PCR. DGGE was carried out on a DCode universal mutation detection system (Bio-Rad, Hemel Hempstead, UK); using $10 \%$ polyacrilamide gels, with denaturant urea-formamide gradients of 10 $50 \%$ for fungi [52] and $40-55 \%$ for bacteria [53], with the concentrations of $7 \mathrm{M}$ urea and $40 \%$ formamide (v/v) for the $100 \%$ denaturant. Electrophoreses were run at $60^{\circ} \mathrm{C} 75 \mathrm{~V}$ for $16 \mathrm{~h}$ and $14 \mathrm{~h}$, for fungi and bacteria respectively, loading equal volumes of amplified DNA. Gels were stained with SYBR Gold nucleic acid stain (Molecular Probes, Leiden, The Netherlands) and digitized using an InGenius3 Imaging System and Genesnap 6.08 (Syngene, Cambridge, UK). DGGE fingerprint profiles were analyzed with a KODAK 1D Image Analysis software (Eastman Kodak Co. 2000; Rochester, NY, USA). Bands were adjusted with a Gaussian model with a profile width of $80 \%$. Noise was eliminated by removing bands below a $10 \%$ band peak intensity threshold. Species 
delimitation can be contended, especially taking into account the inherent limitations of the different analytical methods, such as in the case of DGGE where a unique band does not necessarily represent a unique species and one species can be represented by multiple bands on the gel $[54,55]$. Consequently, each band of the DGGE profile is hereafter referred to as an operational taxonomic unit (OTU) rather than a species. Although this is a simplification of the real taxonomic diversity of soil microbes, it allowed us to comparatively investigate differences and changes in the microbial community structure with respect to the studied factors. Gel bands were analyzed by using internal reference bands (bands present in all lanes), and known reference markers loaded in lanes at either side of the gel. The number and pixel intensity of bands in a particular sample were considered comparative proxies of richness and proportional abundance of fungal or bacterial OTUs, respectively [55]. Similar analysis of DGGE banding patterns have been previously used in other studies [52, 54-58].

\section{Plant-soil system $\mathrm{CO}_{2}$ exchange}

Net ecosystem exchange (NEE), defined as the net balance between Gross Primary Productivity (GPP) and Ecosystem Respiration $\left(\mathrm{R}_{\mathrm{eco}}\right)$, was measured for each individual plant-soil microcosm using a non-steady-state dynamic (closed dynamic) approach. For that purpose, a rectangular plexiglas chamber with a base of $0.01 \mathrm{~m}^{2}$ and a volume of $0.0024 \mathrm{~m}^{3}$ with a small fan to mix the air internally was built to fit over the microcosms (Online Resource 2). The change in $\mathrm{CO}_{2}$ concentrations was measured with a $\mathrm{CO}_{2}$ infrared gas analyzer (EGM-4, PP-systems, MA, USA). The chamber was covered with aluminium foil to determine ecosystem respiration $\left(\mathrm{R}_{\mathrm{eco}}\right)$ including both autotrophic (plants) and heterotrophic (microorganisms) components. Respiration rates were measured in both the transparent and the aluminium chamber for $52 \mathrm{~s}$ before the simulated drought and then every 15 days. During the drought simulation, diurnal $\mathrm{CO}_{2}$ exchange measurements were taken in all microcosms four times per day (7:00-9:00 h, 11:00-13:00 h; 14:00-16:00 h; 18:00-20:00 
h). Soil respiration was determined 3, 24 and $48 \mathrm{~h}$ after rewetting, only at 14:00-16:00 h, which was the period where the maximum activity was previously observed.

NEE (transparent chamber) and $\mathrm{R}_{\mathrm{eco}}$ (opaque chamber) were determined by calculating the $\mathrm{CO}_{2}$ increase in the closed loop (see Online Resource 2) in the respective measurements according to

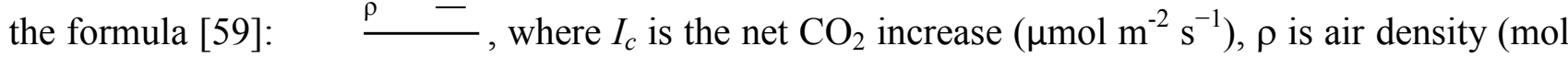
$\left.\mathrm{m}^{-3}\right), V$ the chamber volume $\left(\mathrm{m}^{3}\right), \mathrm{d} C / \mathrm{dt}$ represents the slope of $\mathrm{CO}_{2}$ concentration increase in the chamber over time $\left(\mu \mathrm{mol} \mathrm{mol}{ }^{-1} \mathrm{~s}^{-1}\right)$, and $A$ is the chamber surface area $\left(\mathrm{m}^{2}\right)$. Gross primary productivity (GPP) was calculated by subtracting $\mathrm{R}_{\text {eco }}$ from NEE. The maximum difference between atmospheric $\left(\mathrm{C}_{a}\right)$ and internal $\mathrm{CO}_{2}\left(\mathrm{C}_{i}\right)$ was used to correct for chamber leaks using a linear equation [60].

\section{Data analysis}

The effects of fragment size (large or small), region (north or south) and condition (pre-drought, drought or rewetting) and their interactions were analyzed by three-way Analysis of Variance (ANOVA), with pot as a random effect. The effect of fragment size and region on soil abiotic characteristics, microbial biomass and final seedling measurements (height, diameter, biomass, root/shoot ratio, SLA, water potential) were analyzed by two-way ANOVAs. Repeated-measures ANOVAs were used to test the effect of the same factors during the drought in continuously measured variables (plant physiology and soil moisture). The analysis of survival percentages was carried out with a Peto and Peto test using $X^{2}$ [61].

The diversity of both bacterial and fungal communities was estimated from the number and intensity of bands (OTUs). Richness (S), Shannon $\left(H^{\prime}\right)$ and evenness $\left(\mathrm{E}_{\mathrm{H}}\right)$ diversity indexes were calculated as follows: Shannon

Evenness

where $n_{i}$ is the band intensity, $N$ is the sum of all intensities of a sample and $S$ is the number of bands of a sample (richness). Principal component analysis (PCA) was conducted to reduce the $n$ - 
dimensional DGGE data obtained for each sample into linear axes explaining the maximum amount of variance, using the relative intensity of the bands obtained from the DGGE. We used the first two principal components of the PCA to define the structure of bacterial and fungal communities [58]. With the scores of the principal components of the PCA we explored the effect of soil moisture over the structure of soil microbial communities using three-way ANOVAs with the same factors as above, except the condition (soil moisture) which was tested by pairs (pre-drought vs drought and drought vs rewetting). In all cases, pot was used as a random effect and Tukey's test was used for post-hoc multiple comparisons to determine significant differences.

We performed two correlation analyses: 1) Pearson's correlations (calculated to investigate the univariate relations between variables); and 2) stepwise multiple regressions to study which measured variables best explained the microbial diversity and variations in community structure. To perform stepwise multiple regressions first we reduced the number of explanatory variables to four, eliminating redundant variables (correlation among explanatory variables; see Online Resource 3), and by choosing those variables that generated the highest Pearson's coefficients. A sequential Bonferroni correction was used to account for multiple comparisons [62]. Simple linear regressions were run to analyze moisture sensitivity of carbon fluxes. All variables were tested for normality, and $\log$ transformations were applied when required (GPP, $\mathrm{R}_{\mathrm{eco}}$ and soil moisture), prior to analyses. STATISTICA 8.0 (StatSoft, Inc. 2007; Tulsa OK, USA) was used for performing all analyses.

\section{Results}

\section{Soil characteristics}

In general, the physicochemical characteristics of soils were highly affected by fragment size and less by bioclimatic region (i.e. northern or southern). Soils from smaller fragments showed higher water holding and cation exchange capacities, as well as higher $\mathrm{Mg}^{2+}, \mathrm{Ca}^{2+}$ and $\mathrm{Na}^{+}$concentrations compared with soils from larger fragments (Table 1). Concentration of SOM, nitrogen and 
phosphorus were higher in soils from small than from large fragments, and also higher in the northern region compared to the southern one; whereas $\mathrm{K}^{+}$was higher in small fragments and in the southern region (Table 1). Soils from the northern region presented a significantly less alkaline $\mathrm{pH}$ and more stable aggregates in comparison with those from the southern region. A significant interaction between fragment size and region on soil microbial biomass was also detected (Table 1), showing that microbial biomass was highest in soil from large fragments from the northern region. SOM was strongly correlated with cation exchange capacity, organic nitrogen and $\mathrm{Ca}^{2+}$ (Online Resource 3), as well as with water holding capacity $\left(R^{2}=0.89 \mathrm{p}<0.001\right)$.

During the drought simulation, soils from small fragments of both regions showed higher soil moisture $\left(F_{10,260}=3.7 ; p<0.001\right)$, compared to soils from large fragments, particularly those from the northern region (Online Resource 4 and 5).

\section{Soil microbial diversity}

Significant interactions among condition, region and fragment size was observed in both fungal richness and diversity (Online Resource 6), mainly driven by large fragments from the southern region with the highest values of both variables at pre-drought and after rewetting (Fig. 1a and b).

Similarly, significant interactions between condition, region and fragment size were observed for bacterial richness and between condition and region for bacterial diversity (Online Resource 6). Both interactions showed very similar patterns: a significant decrease of bacterial richness and diversity during drought, and a partial recovery after rewetting (Fig. 1d and e), been more evident in soils from the northern region. Fungal evenness increased significantly with drought (Fig. 1c), while bacterial evenness during drought showed an increase only in the northern region (Fig. 1f).

The first two PCA components explained $20.5 \%$ of the total variance in the fungal community composition (Fig. 2a). The pre-drought fungal community was strongly influenced by region, but not by fragment size (Table 2). A high variability was observed in the fungal community 
from the northern region (Fig. 2a). Under drought, an interaction between drought and region was observed (Table 2, Fig. 2a). Once soils were rewetted, the fungal community structure was significantly affected by region and fragment size (Table 2, Fig. 2a). In the case of bacterial community composition, the first two PCA components explained $33.2 \%$ of the total variance (Fig. $2 b)$. Neither region nor fragment size affected the structure of the pre-drought bacterial community (Table 2, Fig. 2b). Both drought and rewetting led to a significant separation of the structure of bacterial communities from different regions, according to the principal component 1 of the PCA (Table 2, Fig. 2b). Fragment size and its interaction with drought and rewetting had no significant effect over the structure of microbial communities.

\section{Enzymatic activity}

Significant interaction between all factors (condition*region*fragment size) was observed for urease activity, with higher activity in soils from small fragments of the southern region at predrought (Fig. 3a), but higher activity in soil from small fragments of the northern region during simulated drought and rewetting. For phosphatase activity, fragment size showed a significant main effect $\left(F_{1,1}=9.53 ; p=0.005\right)$ with higher activity in soils from small fragments (Online Resource 6 ). Additionally, a significant interaction between condition and region was observed, where activity in soils from the northern region decreased significantly with drought (Fig. 3b); whereas activity in soils from the southern region remained very similar during the experiment.

\section{Net ecosystem exchange in plant-soil-microbial system}

In the plant-soil-microbial system, the main component of net ecosystem exchange (NEE) was ecosystem respiration $\left(\mathrm{R}_{\mathrm{eco}}\right)$, with a lower contribution of gross primary productivity (GPP; Fig. 4). Drought caused an overall significant decrease in both $\mathrm{R}_{\mathrm{eco}}$ and GPP (Fig. 4a and b, respectively; Online Resource 7). A consistent significant interaction between region and fragment size was 
detected, showing that the soils from small fragments of the northern region had higher $\mathrm{R}_{\mathrm{eco} \text {, during }}$ the drought simulation (Fig. 4a; Online Resource 7). A significant interaction between time, region and fragment size was observed in the pulse of $\mathrm{CO}_{2}$ after rewetting (Online Resource 8), showing higher $\mathrm{R}_{\text {eco }}$ in soils from the northern region especially at 3 and 48 hrs (Fig. 4c).

\section{Plant growth and physiology}

Growth and physiological activity of seedlings were not affected by region or fragment size (Table 3 , Online Resource 5), despite the differences in moisture and nutrient status observed between soils (Table 1). However, the physiological activity of seedlings was significantly affected by drought (Online Resource 5). Seedlings grown in soils from the southern region showed the lowest SLA (Table 3). Seedling survival varied significantly depending upon treatments, from no mortality in soils of small fragments from the northern region, to almost $50 \%$ seedling mortality in soils of large fragments from the southern region (Table 3). We did not find any consistent relationships between seedling growth (height, diameter, biomass, SLA), physiology (GPP, photochemical efficiency, stomatal conductance, water potential), and soil microbial communities (bacterial and fungal diversity and structure), soil biogeochemical properties (nutrients, soil moisture, stability), or soil functioning (enzymatic activity, $\mathrm{R}_{\text {eco; }}$ Online Resource 9).

\section{Influence of soil moisture on the plant-soil-microbial system}

Linear regression analyses showed that $R_{\text {eco }}$ was highly sensitive to soil moisture $\left(R^{2}=0.499\right.$, $p<0.001$ ) (Fig. 5a), whereas GPP was not (Fig. 5b). As expected, correlations showed that soil functioning ( $\mathrm{R}_{\text {eco }}$ and enzymatic activities) were strongly related to soil moisture (Table 4). Fungal community structure (i.e. PC1 of fungal PCA; Fig. 2a) was negatively correlated with $\mathrm{R}_{\mathrm{eco}}$ and phosphatase activity (Table 4). Fungal diversity was negatively correlated with $\mathrm{R}_{\text {eco }}$ and both enzyme activities (Table 4). Bacterial community structure (i.e. PC1 of bacterial PCA; Fig. 2b) was 
positively correlated with $\mathrm{R}_{\text {eco }}$ and urease activity (Table 4). Bacterial richness and diversity were also correlated with $\mathrm{R}_{\text {eco }}$ and phosphatase activity (Table 4).

Results of the stepwise multiple regressions showed a strong relationship between soil moisture and the diversity and structure of microbial communities (Table 5). However, an opposite relationship with soil moisture was detected for the two microbial communities, with soil moisture negatively correlated with fungal structure and diversity and positively correlated with bacteria structure (Table 5). Furthermore, fungal community evenness was significantly affected by $\mathrm{pH}$, aggregate stability and SOM, whereas fungal diversity was also affected by SOM (Table 5).

\section{Discussion}

Effects of the fragment size and the bioclimatic region over the plant-soil-microbial system

In our study the physicochemical characteristics of soils were highly affected by fragment size and less by the bioclimatic region (i.e. northern vs. southern region). Soils from small fragments of both regions showed higher concentrations of essential ions, partially confirming our initial hypothesis that physicochemical characteristics of soils would differ in forest fragments of contrasting sizes. In a fragmented forest, the influence of the agricultural matrix tends to increase as the fragments become smaller due to an amplified relative importance of edge effects [10]. This influence over the physicochemical characteristic of small fragments and of the edge of large fragments tend to be higher when the matrix is agricultural [63]. Among other factors (lower tree competition and higher light availability), this increased fertility mediated by the matrix could also explain the presence of larger and more productive trees growing in the smaller fragments at both sites (authors personal observations), which are leading to more soil organic matter (SOM) accumulation in these soils. Soil water holding capacity was also higher in soils from small fragments, probably due to their higher SOM content, which typically increases the capacity of a soil to retain water $[64,65]$. This increase in resources under small fragments was also reflected in an 
increase in the functionality of the plant-soil-microbial system; both $\mathrm{R}_{\mathrm{eco}}$ and phosphatase activities were higher in soils from small fragments sizes in both regions.

Unlike functional indicators, our results indicate that the microbial communities were more sensitive to the particular bioclimatic conditions of the two regions studied than to the size of the fragment. Under a low influence of the matrix (large fragments), soils from the colder and wetter region (northern) had higher microbial biomass and a more bacterial-rich community, while soils from the warmer and drier southern region had the lowest values of microbial biomass but the most diverse fungal communities. However, fragment size did not significantly affect the diversity and structure of the microbial communities, suggesting a strong resistance [37] of these communities to the potential changes in soil physicochemical properties associated with fragment size.

Effects of climatic simulations over the functioning of the plant-soil-microbial system and its interactions with fragment size and bioclimatic origin

Drought negatively affected the plant-soil-microbial system due to the strong effect of soil moisture over different functional indicators of the plant-soil-microbial system, such as autotrophic and heterotrophic respiration as well as plant productivity [18-20]. Decreases in metabolic activity related to drought have been found in other studies for both soil [66, 67], and enzymatic activities [68-70]. A synchrony in the reduction of $R_{\text {eco }}$ and enzymatic activity was expected when the microcosms were water-limited since both processes involve microbial aerobic activity, largely depend upon adequate water conditions [17-20, 67-71]. On the contrary, the observed lower effect of drought over GPP (only significant by the end of the drought) evidenced a higher resistance to drought of these seedlings with respect to microbes. This higher resistance to drought could be due to a higher capacity of plants to explore the water resources of soil than microorganisms, which are more static and dependants on water micro-conditions [17, 21, 23, 29, 31]. 
Regarding microbial communities, the forced climatic simulations (drought and rewetting) were associated with strong and opposed fluctuations in the diversity of both bacteria and fungi. The observed increase in fungal richness and diversity together with the decrease in bacterial diversity during the drought reinforces the idea that fungi overcome water limitations better than bacteria $[24$, 27-29, 34, 38]. This can be explained because bacteria are organisms evolved in aqueous environment, and are more diverse under optimal water conditions, while fungi are organisms evolved in terrestrial environments, tending to be more diverse under water limitations $[29,34,38]$. This was in agreement with the fact that soil rewetting produced an opposite effect with respect to that observed for drought on the microbial communities, decreasing fungal diversity and increasing bacterial diversity, respectively.

Collectively, our results suggest that the bioclimatic origin of the soil microbial communities strongly determined both the modulation by fragmentation of the effect of drought and the capacity of the microbial community to respond to the simulated climatic fluctuations. Our results only partially support our second hypothesis i.e. that the functional response of the plant-soil-microbial system to climatic simulations (drought and rewetting) would be determined by the particular initial microbial communities and biogeochemical soil properties associated with fragment size. Only in the small fragments of the northern and wetter region the initial biological and physicochemical soil properties (e.g. higher bacterial richness and SOM content) appeared to have a strong positive effect over the functioning of the plant-soil-microbial system during drought (increasing $\mathrm{R}_{\mathrm{eco}}$, GPP, urease activity under dry condition in small with respect to large fragments), whereas fragment size have less of an effect (significant only for GPP) in the southern and drier region. The sensitivity of the microbial communities (diversity and evenness) to the climatic simulations was also strongly dependent on the initial bioclimatic origin of the soils. Indeed, the stronger sensitivity of bacterial diversity and evenness from the northern (colder and wetter) with respect to the southern (warmer and drier) region indicates a different degree of historical adaptation to dry conditions from these two 
communities. It is therefore likely that the harsher historical climatic conditions in the southern region may have acted as a strong habitat filter by selecting drought tolerant microbial species, more resistant to the simulated dry conditions of the experiment $[72,73]$. In turn, the fast and significant increase in bacterial richness and diversity together with the strong pulse in $\mathrm{CO}_{2}$ after rewetting again suggest that soil microbial communities grown in soils from the northern region, richer in organic matter, were more resilient to changes in water availability. Therefore, whereas reducing the size of the fragment increases the fertility and water availability for both microbes and plants (hence ameliorating the effect of drought over the functioning of the plant-soil-microbial system), the lack of sensitivity to this increase in resources of the plant-soil-microbial systems with soils from the southern region could only indicate a lack of responsiveness of the soil microbial communities from this drier site, which were unable to recover the function.

\section{Conclusions}

A schematic overview of the main findings from this study is shown in Figure 6, ilustrating a continuum of drier to wetter conditions of soil and the interplay between the two climatically different regions and the fragment sizes. We observed here that, under optimal conditions (no water limitations) and in soils from the wetter region, the highest metabolic rates $\left(\mathrm{R}_{\mathrm{eco}}\right.$ and enzyme activities) were generally associated with microbial communities dominated by rich bacterial communities, whereas under drought and in the southern and drier region, the relatively lower metabolic rates were associated with microbial communities dominated by rich fungal communities. Under drought stress, fragmentation modulates the functional response of both plants and microbes, especially in the relatively richer soils from the northern region, whereas fragment size did not substantially modulate the functional response of the microcosms with soils from the southern and drier region. 
Our results, therefore, suggest that the drier conditions expected in the future for the already water limited Mediterranean basin will favour fungal-dominated soil microbial communities, leading to a slowdown of processes associated with the plant-soil-microbial system. Moreover, the interaction found here between drought and fragment size suggests that habitat fragmentation could, ameliorate to some extent and depending on the local bioclimatic conditions and soil physicochemical characteristics, the negative effect of increasing droughts by increasing the fertility and water holding capacity of soils.

\section{Acknowledgments}

We thank O. Pérez-Priego for assistance designing the $\mathrm{CO}_{2}$ exchange-measuring chamber and to $\mathrm{D}$. López-Quiroga for helping with its assembly. We also thank D. Elliott for his assistance with the DGGE community fingerprinting, and T. Morán-López for her help with the statistical analyses. We thank the anonymous referees for all their constructive comments and advice. This work was supported by the Spanish Ministry for Economy and Competitiveness (formerly known as Innovation and Science) with the project VULGLO (CGL2010 22180 C03 03); and the projects REMEDINAL 2 (CM S2009 AMB 1783) and MICROAMBIENTE (S2009/AMB-1511), funded by the Comunidad de Madrid. DFR holds a pre-doctoral fellowship awarded by the Mexican Council of Science and Technology (CONACyT).

\section{References}

1. IPCC (2007) Climate Change 2007 - Syntesis report. IPCC, Intergovernmental Panel on Climate Change c/o World Meteorological Organization (WMO).

2. Valladares F, Benavides R, Rabasa SG, Pausas JG, Paula S, Simonson WD, Díaz M (2014)

Global Change and Mediterranean forest: current impacts and potential responses. In: 
Coomes, DA, Burslem, DFRP, Simonson, WD (eds.) Forests and Global Change. Cambridge University Press, Cambridge, UK, pp. 47-76

3. Didham RK, Ghazoul J, Stork NE, Davis AJ (1996) Insects in fragmented forests: a functional approach. Trends Ecol Evol 11: 255-260. doi: http://dx.doi.org/10.1016/01695347(96)20047-3

4. Fischer J, Lindenmayer DB (2007) Landscape modification and habitat fragmentation: a synthesis. Global Ecol Biogeogr 16: 265-280. doi: 10.1111/j.1466-8238.2007.00287.x

5. Fahrig L (2003) Effects of habitat fragmentation on biodiversity. Annu Rev Ecol, Evol Syst 34: 487-515. doi: 10.1146/annurev.ecolsys.34.011802.132419

6. Rantalainen M-L, Haimi J, Fritze H, Pennanen T, Setälä H (2008) Soil decomposer community as a model system in studying the effects of habitat fragmentation and habitat corridors. Soil Biol Biochem 40: 853-863. doi:

http://dx.doi.org/10.1016/j.soilbio.2007.11.008

7. Dooley JL, Bowers MA (1998) Demographic responses to habitat fragmentation: experimental tests at the landscape and patch scale. Ecology 79: 969-980. doi: 10.1890/00129658(1998)079[0969:DRTHFE]2.0.CO;2

8. Díaz M, Santos T, Tellería JL (1999) Effects of forest fragmentation on the winter body condition and population parameters of an habitat generalist, the wood mouse Apodemus sylvaticus: a test of hypotheses. Acta Oecol 20: 39-49. doi: http://dx.doi.org/10.1016/S1146609X(99)80014-9

9. Lindenmayer DB, Fischer J (2006) Habitat fragmentation and landscape change: an ecological and conservation synthesis. Island Press, Washington, USA

10. Fernández C, Acosta FJ, Abellá G, López F, Díaz M (2002) Complex edge effect fields as additive processes in patches of ecological systems. Ecol Model 149: 273-283. 
11. Zanette L, Doyle P, Tremont SM (2000) Food shortage in small fragments: evidence from an area-sensitive passerine. Ecology 81: 1654-1666. doi: http://dx.doi.org/10.1890/00129658(2000)081[1654:FSISFE]2.0.CO;210.2307/177314

12. Valladares F, Camarero JJ, Pulido F, Gil-Pelegrín E (2004) El bosque mediterráneo, un sistema humanizado y dinámico. In: Valladares, F (ed.) Ecologia del Bosque Mediterráneo en un mundo cambiante. Ministerio del Medio Ambiente, Madrid, Spain, pp. 13-25

13. Millennium-Ecosystem-Assessment (2005) Ecosystems and Human Well-being: Synthesis. Island Press, Washington, DC.

14. Santos T, Tellería JL (1998) Efectos de la fragmentación de los bosques sobre los vertebrados de las mesetas ibéricas. Organismo Autónomo "Parques Nacionales", Madrid, Spain

15. Díaz M, Alonso CL (2003) Wood mouse Apodemus sylvaticus winter food supply: density, condition, breeding, and parasites. Ecology 84: 2680-2691.

16. Lázaro-Nogal A, Matesanz S, Gimeno T, Escudero A, Valladares F (2012) Fragmentation modulates the strong impact of habitat quality and plant cover on fertility and microbial activity of semiarid gypsum soils. Plant Soil 358: 213-223. doi: 10.1007/s11104-012-1184-9

17. Rambal S, Ourcival J-M, Joffre R, Mouillot F, Nouvellon Y, Reichstein M, Rocheteau A (2003) Drought controls over conductance and assimilation of a Mediterranean evergreen ecosystem: scaling from leaf to canopy. Global Change Biol 9: 1813-1824. doi: 10.1111/j.1365-2486.2003.00687.x

18. Barba J, Curiel Yuste J, Martínez-Vilalta J, Lloret F (2013) Drought-induced tree species replacement is reflected in the spatial variability of soil respiration in a mixed Mediterranean forest. For Ecol Manage 306: 79-87. doi: http://dx.doi.org/10.1016/j.foreco.2013.06.025

19. Orchard VA, Cook FJ (1983) Relationship between soil respiration and soil moisture. Soil Biol Biochem 15: 447-453. doi: http://dx.doi.org/10.1016/0038-0717(83)90010-X 
20. Reichstein M, Tenhunen JD, Roupsard O, Ourcival J-m, Rambal S, Miglietta F, Peressotti A, Pecchiari M, Tirone G, Valentini R (2002) Severe drought effects on ecosystem $\mathrm{CO}_{2}$ and $\mathrm{H}_{2} \mathrm{O}$ fluxes at three Mediterranean evergreen sites: revision of current hypotheses? Global Change Biol 8: 999-1017. doi: 10.1046/j.1365-2486.2002.00530.x

21. Ogaya R, Peñuelas J (2004) Phenological patterns of Quercus ilex, Phillyrea latifolia, and Arbutus unedo growing under field experimental drought. Ecoscience 11: 263-270.

22. Hereş A-M, Martínez-Vilalta J, Claramunt López B (2012) Growth patterns in relation to drought-induced mortality at two Scots pine (Pinus sylvestris L.) sites in NE Iberian Peninsula. Trees-Struct Funct 26: 621-630. doi: 10.1007/s00468-011-0628-9

23. Castro HF, Classen AT, Austin EE, Norby RJ, Schadt CW (2010) Soil microbial community responses to multiple experimental climate change drivers. Appl Environ Microbiol 76: 9991007. doi: 10.1128/aem.02874-09

24. Barnard RL, Osborne CA, Firestone MK (2013) Responses of soil bacterial and fungal communities to extreme desiccation and rewetting. ISME J 7: 2229-2241. doi: 10.1038/ismej.2013.104

25. Williams MA (2007) Response of microbial communities to water stress in irrigated and drought-prone tallgrass prairie soils. Soil Biol Biochem 39: 2750-2757. doi: http://dx.doi.org/10.1016/j.soilbio.2007.05.025

26. Treseder K, Balser T, Bradford M, Brodie E, Dubinsky E, Eviner V, Hofmockel K, Lennon J, Levine U, MacGregor B, Pett-Ridge J, Waldrop MP (2012) Integrating microbial ecology into ecosystem models: challenges and priorities. Biogeochemistry 109: 7-18. doi: 10.1007/s10533-011-9636-5

27. Schimel JP, Balser TC, Wallenstein MD (2007) Microbial stress-response physiology and its implications for ecosystem function. Ecology 88: 1386-1394. doi: 10.1890/06-0219 
28. Drenovsky RE, Vo D, Graham KJ, Scow KM (2004) Soil water content and organic carbon availability are major determinants of soil microbial community composition. Microb Ecol 48: 424-430. doi: 10.1007/s00248-003-1063-2

29. Curiel Yuste J, Peñuelas J, Estiarte M, Garcia-Mas J, Mattana S, Ogaya R, Pujol M, Sardans J (2011) Drought-resistant fungi control soil organic matter decomposition and its response to temperature. Global Change Biol 17: 1475-1486. doi: 10.1111/j.1365-2486.2010.02300.x

30. Wardle DA, Bardgett RD, Klironomos JN, Setälä H, van der Putten WH, Wall DH (2004) Ecological linkages between aboveground and belowground biota. Science 304: 1629-1633. doi: $10.1126 /$ science. 1094875

31. de Vries FT, Liiri ME, Bjornlund L, Bowker MA, Christensen S, Setala H, Bardgett RD (2012) Land use alters the resistance and resilience of soil food webs to drought. Nature Clim Change 2: 276-280. doi: http://dx.doi.org/10.1038/nclimate1368

32. Bahn M, Lattanzi FA, Hasibeder R, Wild B, Koranda M, Danese V, Brüggemann N, Schmitt M, Siegwolf R, Richter A (2013) Responses of belowground carbon allocation dynamics to extended shading in mountain grassland. New Phytol 198: 116-126. doi: 10.1111/nph.12138

33. Evans SE, Wallenstein MD, Burke IC (2013) Is bacterial moisture niche a good predictor of shifts in community composition under long-term drought? Ecology 95: 110-122. doi: $10.1890 / 13-0500.1$

34. Göransson H, Godbold DL, Jones DL, Rousk J (2013) Bacterial growth and respiration responses upon rewetting dry forest soils: impact of drought-legacy. Soil Biol Biochem 57: 477-486. doi: http://dx.doi.org/10.1016/j.soilbio.2012.08.031

35. Fuchslueger L, Bahn M, Fritz K, Hasibeder R, Richter A (2014) Experimental drought reduces the transfer of recently fixed plant carbon to soil microbes and alters the bacterial community composition in a mountain meadow. New Phytol 201: 916-927. doi: 10.1111/nph.12569 
36. Wagg C, Bender SF, Widmer F, van der Heijden MGA (2014) Soil biodiversity and soil community composition determine ecosystem multifunctionality. Proc Natl Acad Sci USA: 1-5. doi: 10.1073/pnas. 1320054111

37. Allison SD, Martiny JB (2008) Resistance, resilience, and redundancy in microbial communities. Proc Natl Acad Sci USA 105: 11512-11519. doi: 10.1073/pnas.0801925105

38. Grigulis K, Lavorel S, Krainer U, Legay N, Baxendale C, Dumont M, Kastl E, Arnoldi C, Bardgett RD, Poly F, Pommier T, Schloter M, Tappeiner U, Bahn M, Clément J-C (2013) Relative contributions of plant traits and soil microbial properties to mountain grassland ecosystem services. J Ecol 101: 47-57. doi: 10.1111/1365-2745.12014

39. Ninyerola M, Pons X, Roure JM (2005) Atlas climático digital de la Península Ibérica. Metodología y aplicaciones en bioclimatología y geobotánica. Universidad Autónoma de Barcelona. http://www.opengis.uab.es/wms/iberia/index.htm. Accessed 30/04/2014 2014

40. Rivas-Martínez S (1981) Les étages bioclimatiques de la végétation de la Péninsule Ibérique. Anales del Jardín Botánico de Madrid 37: 251-268.

41. WRB IWG (2007) World Reference Base for Soil Resources 2006, first update 2007. In: Reports, WSR (ed.) FAO, vol. 103, Rome, Italy, pp. 116.

42. Díaz M, Santos T, Telleria JL (1999) Effects of forest fragmentation on the winter body condition and population parameters of an habitat generalist, the wood mouse Apodemus sylvaticus: a test of hypotheses. Acta Oecologica-International Journal of Ecology 20: 39-49. doi: 10.1016/s1146-609x(99)80014-9

43. Imeson AC, Vis M (1984) Assessing soil aggregate stability by water-drop impact and ultrasonic dispersion. Geoderma 34: 185-200. doi: http://dx.doi.org/10.1016/00167061(84)90038-7

44. Bremner JM (1960) Determination of nitrogen in soil by the Kjeldahl method. J Agric Sci 55: 11-33. doi: $10.1017 / \mathrm{S} 0021859600021572$ 
45. Burriel F, Hernando V (1950) Extraction of the total phosphorus from Spanish soils. Transactions 4th Int Cong Soil Sci, vol. 2, pp. 133-134.

46. Gregorich EG, Wen G, Voroney RP, Kachanoski RG (1990) Calibration of a rapid direct chloroform extraction method for measuring soil microbial biomass C. Soil Biol Biochem 22: 1009-1011. doi: http://dx.doi.org/10.1016/0038-0717(85)90144-0

47. Scholander PF, Bradstreet ED, Hemmingsen EA, Hammel HT (1965) Sap pressure in vascular plants: negative hydrostatic pressure can be measured in plants. Science 148: 339346.

48. Tabatabai MA (1994) Soil Enzymes. In: Weaver, RW, Angle, JS, Bottomley, PS (eds.) Methods of Soil Analysis: Part 2-Microbiological and Biochemical Properties. Soil Science Society of America, Madison, USA, pp. 775-833

49. Nannipieri P, Ceccanti B, Cervelli S, Matarese E (1980) Extraction of phosphatase, urease, proteases, organic carbon, and nitrogen from soil. Soil Sci Soc Am J 44: 1011-1016. doi: $10.2136 /$ sssaj $1980.03615995004400050028 x$

50. Gardes M, Bruns TD (1993) ITS primers with enhanced specificity for basidiomycetes application to the identification of mycorrhizae and rusts. Mol Ecol 2: 113-118. doi: 10.1111/j.1365-294X.1993.tb00005.X

51. Muyzer G, de Waal EC, Uitterlinden AG (1993) Profiling of complex microbial populations by denaturing gradient gel electrophoresis analysis of polymerase chain reaction-amplified genes coding for 16S rRNA. Appl Environ Microbiol 59: 695-700.

52. Anderson IC, Campbell CD, Prosser JI (2003) Diversity of fungi in organic soils under a moorland - Scots pine (Pinus sylvestris L.) gradient. Environ Microbiol 5: 1121-1132. doi: 10.1046/j.1462-2920.2003.00522.x

53. Grossman J, O’Neill B, Tsai S, Liang B, Neves E, Lehmann J, Thies J (2010) Amazonian anthrosols support similar microbial communities that differ distinctly from those extant in 
adjacent, unmodified soils of the same mineralogy. Microb Ecol 60: 192-205. doi: $10.1007 / \mathrm{s} 00248-010-9689-3$

54. Vaz-Moreira I, Egas C, Nunes OC, Manaia CM (2013) Bacterial diversity from the source to the tap: a comparative study based on 16S rRNA gene-DGGE and culture-dependent methods. FEMS Microbiol Ecol 83: 361-374. doi: 10.1111/1574-6941.12002

55. Cleary DFR, Smalla K, Mendonça-Hagler LCS, Gomes NCM (2012) Assessment of variation in bacterial composition among microhabitats in a mangrove environment using DGGE fingerprints and barcoded pyrosequencing. PLoS ONE 7: e29380. doi: 10.1371/journal.pone.0029380

56. Gafan GP, Lucas VS, Roberts GJ, Petrie A, Wilson M, Spratt DA (2005) Statistical analyses of complex denaturing gradient gel electrophoresis profiles. J Clin Microbiol 43: 3971-3978. doi: $10.1128 / \mathrm{jcm} .43 .8 .3971-3978.2005$

57. Farnleitner AH, Zibuschka F, Burtscher MM, Lindner G, Reischer G, Mach RL (2004) Eubacterial 16S-rDNA amplicon profiling: a rapid technique for comparison and differentiation of heterotrophic plate count communities from drinking water. Int J Food Microbiol 92: 333-345. doi: http://dx.doi.org/10.1016/j.ijfoodmicro.2003.08.014

58. Suzuki C, Takenaka M, Oka N, Nagaoka K, Karasawa T (2012) A DGGE analysis shows that crop rotation systems influence the bacterial and fungal communities in soils. Soil Sci Plant Nutr 58: 288-296. doi: 10.1080/00380768.2012.694119

59. Street LE, Shaver GR, Williams MA, Van Wijk MT (2007) What is the relationship between changes in canopy leaf area and changes in photosynthetic $\mathrm{CO}_{2}$ flux in arctic ecosystems? J Ecol 95: 139-150. doi: 10.1111/j.1365-2745.2006.01187.x

60. Pérez-Priego O, Testi L, Orgaz F, Villalobos FJ (2010) A large closed canopy chamber for measuring $\mathrm{CO}_{2}$ and water vapour exchange of whole trees. Environ Exp Bot 68: 131-138. doi: http://dx.doi.org/10.1016/j.envexpbot.2009.10.009 
61. Pyke DA, Thompson JN (1986) Statistical analysis of survival and removal rate experiments. Ecology 67: 240-245. doi: 10.2307/1938523

62. Hill T, Lewicki P (2005) Statistics: Methods and Applications StatSoft, Inc.

63. Boutin C, Jobin Bt (1998) Intensity of agricultural practices and effects on adjacent habitats. Ecol Appl 8: 544-557. doi: 10.1890/1051-0761(1998)008[0544:IOAPAE]2.0.CO;2

64. Franzluebbers AJ (2002) Water infiltration and soil structure related to organic matter and its stratification with depth. Soil Till Res 66: 197-205. doi: http://dx.doi.org/10.1016/S01671987(02)00027-2

65. Boix-Fayos C, Calvo-Cases A, Imeson AC, Soriano-Soto MD (2001) Influence of soil properties on the aggregation of some Mediterranean soils and the use of aggregate size and stability as land degradation indicators. Catena 44: 47-67. doi: http://dx.doi.org/10.1016/S0341-8162(00)00176-4

66. Rey A, Jarvis P (2006) Modelling the effect of temperature on carbon mineralization rates across a network of European forest sites (FORCAST). Global Change Biol 12: 1894-1908. doi: $10.1111 / j .1365-2486.2006 .01230 . x$

67. Curiel Yuste J, Baldocchi DD, Gershenson A, Goldstein A, Misson L, Wong S (2007) Microbial soil respiration and its dependency on carbon inputs, soil temperature and moisture. Global Change Biol 13: 2018-2035. doi: 10.1111/j.1365-2486.2007.01415.x

68. Zornoza R, Guerrero C, Mataix-Solera J, Arcenegui V, García-Orenes F, Mataix-Beneyto J (2006) Assessing air-drying and rewetting pre-treatment effect on some soil enzyme activities under Mediterranean conditions. Soil Biol Biochem 38: 2125-2134. doi: http://dx.doi.org/10.1016/j.soilbio.2006.01.010

69. Hueso S, Hernández T, García C (2011) Resistance and resilience of the soil microbial biomass to severe drought in semiarid soils: the importance of organic amendments. Appl Soil Ecol 50: 27-36. doi: http://dx.doi.org/10.1016/j.apsoil.2011.07.014 
70. Sardans J, Peñuelas J (2005) Drought decreases soil enzyme activity in a Mediterranean Quercus ilex L. forest. Soil Biol Biochem 37: 455-461. doi:

http://dx.doi.org/10.1016/j.soilbio.2004.08.004

71. Schimel JP, Boot C, Holden P, Roux-Michollet D, Parker S, Schaeffer S, Treseder K (2010) Enzyme activity and adaptation in dry soil. Proc World Cong Soil Sci 19: 17-20.

72. Curiel Yuste J, Fernandez-Gonzalez AJ, Fernandez-Lopez M, Ogaya R, Penuelas J, Sardans J, Lloret F (2014) Strong functional stability of soil microbial communities under semiarid Mediterranean conditions and subjected to long-term shifts in baseline precipitation. Soil Biol Biochem 69: 223-233. doi: http://dx.doi.org/10.1016/j.soilbio.2013.10.045

73. Evans SE, Wallenstein MD (2014) Climate change alters ecological strategies of soil bacteria. Ecol Lett 17: 155-164. doi: 10.1111/ele.12206 


\section{Figure captions}

Fig. 1 Response of richness, Shannon diversity and evenness of fungal (a, b, c) and bacterial (d, e, f) communities of soils from two climatically different regions and two fragment sizes of Holm oak forests in Spain, to experimental simulation of drought and rewetting. Grey/white bars represent large/small fragments, respectively. Open/filled bars represent the northern or the southern region respectively. Data $=$ mean \pm SE. Significant differences given by post-hoc multiple comparisons by Tukey's test $(P<0.05)$ of the three-way ANOVA are indicated: main effects by capital letters (among condition) and significant interaction between factors by lower case letters (triple in the case of $a, b$ and d; condition*region in the case of e and f; see Online Resource 6).

Fig. 2 Principal component analyses (PCA) for soil fungal (a) and bacterial (b) communities of soils from two climatically different regions and two fragment sizes of Holm oak forests in Spain, and exposed to experimental drought and rewetting simulations. Soil treatments are represented by different symbols: circles $=$ large fragments from the northern region; inverted triangles $=$ small fragments from the northern region; squares $=$ large fragments from the southern region; diamonds $=$ small fragments from the southern region. Simulated experimental conditions are represented by different colours: white $=$ pre-drought $($ Pre-Dro); grey $=$ drought $($ Dro $)$; black $=$ rewetting $($ Rew $)$. Error bars $=\mathrm{SE}$.

Fig. 3 Enzymatic activities: urease (a) and phosphatase (b) of soils from two climatically different regions and two fragment sizes of Holm oak forests in Spain, and exposed to experimental drought and rewetting simulations. Grey/white bars represent large/small fragments respectively. Open/filled bars represent the northern or the southern region, respectively. Data $=$ means \pm SE. Significant differences given by post-hoc multiple comparisons by Tukey's test $(P<0.05)$ of the three-way ANOVA are indicated: main effect of fragment size in phosphatase activity (not represented), and 
significant interaction between factors by lower case letters (triple in the case of urease; condition*region in the case of phosphatase; see Online Resource 6).

Fig. $4 \mathrm{CO}_{2}$ fluxes of the plant-soil-microbial system of soils from two climatically different regions and two fragment sizes of Holm oak forests in Spain. Ecosystem respiration (a) and Gross primary productivity (b) both in drought simulation, and ecosystem respiration in rewetting simulation (c), where 0 means immediately before rewetting. Grey/white bars represent large/small fragments respectively. Open/filled bars represent the northern or the southern region, respectively. Data = means \pm SE. Significant differences given by post-hoc multiple comparisons by Tukey's test $(P<0.05)$ of the three-way ANOVA are indicated: main effects by capital letters (among condition) and significant triple interaction between factors by lower case letters (condition*region*fragment size, see Online Resources 7 and 8).

Fig. 5 Relationships between Ecosystem Respiration (a), Gross Primary Productivity (b) and soil moisture from two climatically different regions and two fragment sizes of Holm oak forests in Spain exposed to experimental drought and rewetting simulations. Soil treatments are represented by different symbols: grey circles $=$ large fragments from the northern region; white inverted triangles $=$ small fragments from the northern region; grey squares = large fragments from the southern region; white diamonds $=$ small fragments from the southern region. $R^{2}$ and $P$ values of simple linear regressions are presented.

Fig. 6 Schematic overview of simultaneous variations in fungal and bacterial richness, soil moisture, ecosystem functioning and their modulation though fragment size, as suggested by the results of the present study. 


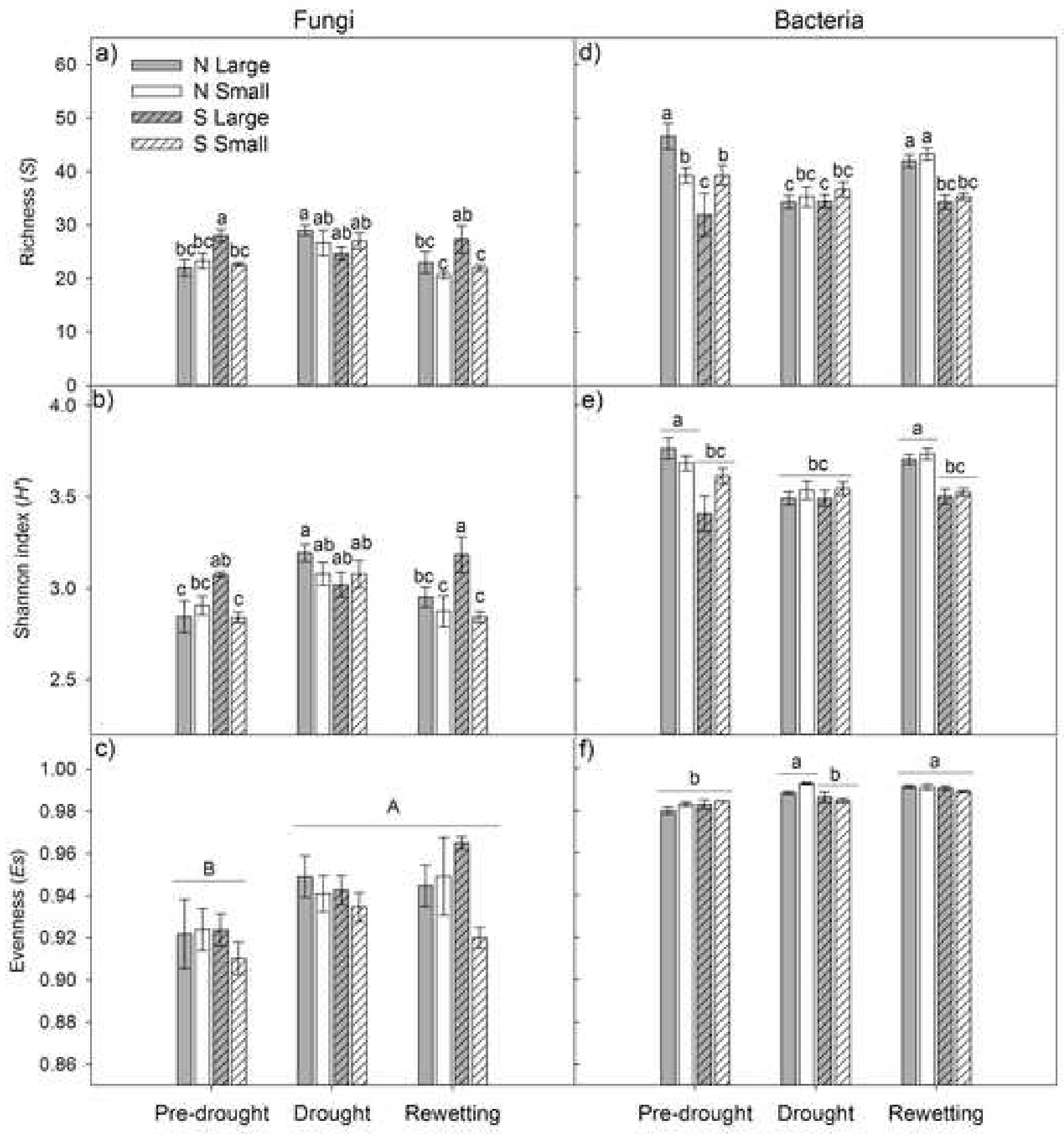



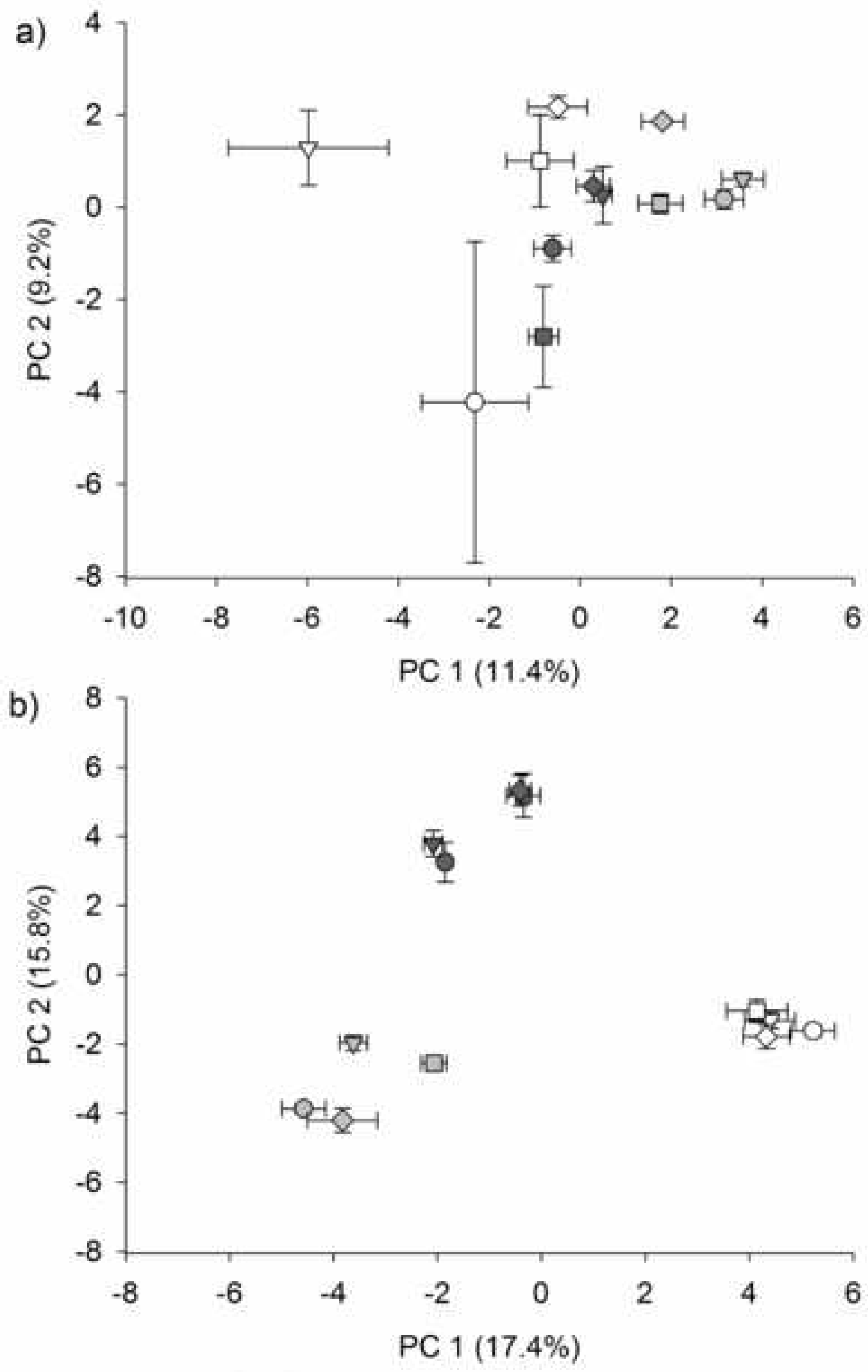
- N Large-Pre-Dro
- N Large-Dro
- N Large-Rew
$\nabla \quad$ N Small-Pre-Dro
$\nabla \quad$ N Small-Dro
N Small-Rew
$\checkmark \quad$ S Large-Pre-Dro
a S Large-Dro
S Large-Rew
$\diamond$ S Small-Pre-Dro $\diamond$ S Small-Dro
S Small-Rew 

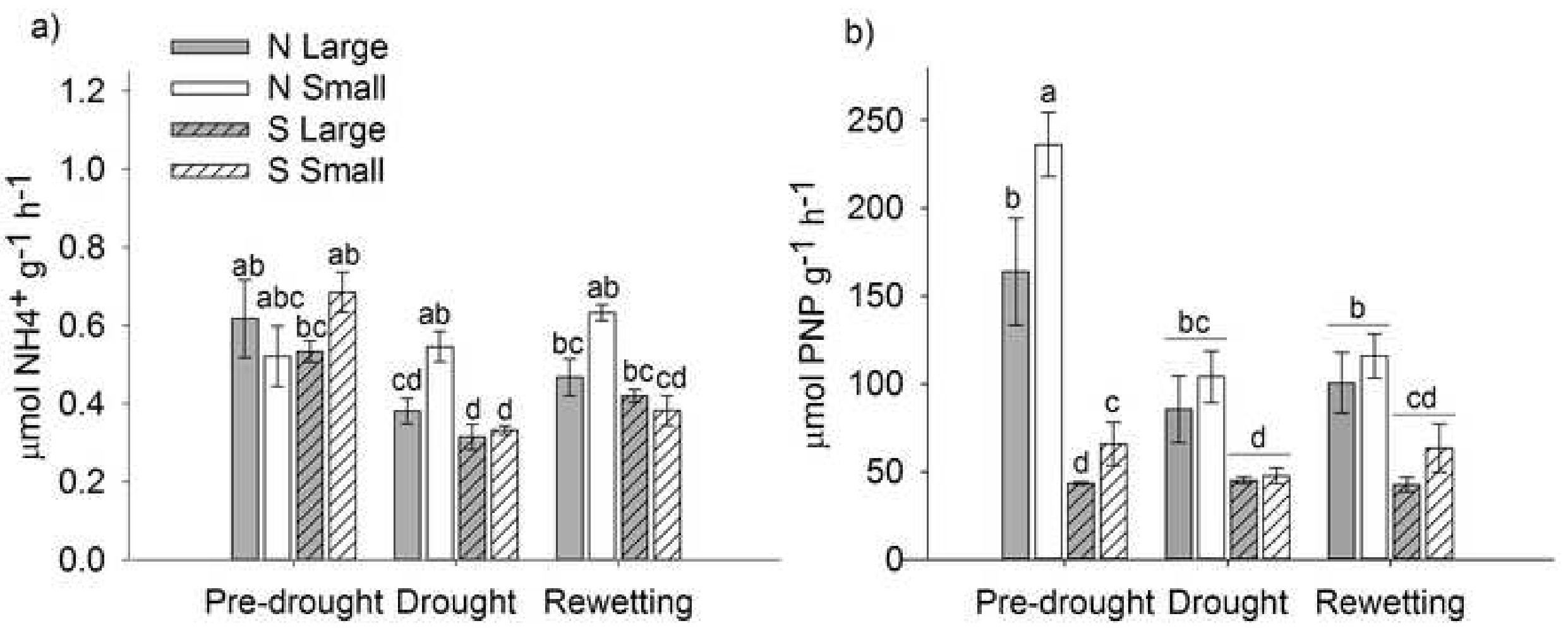

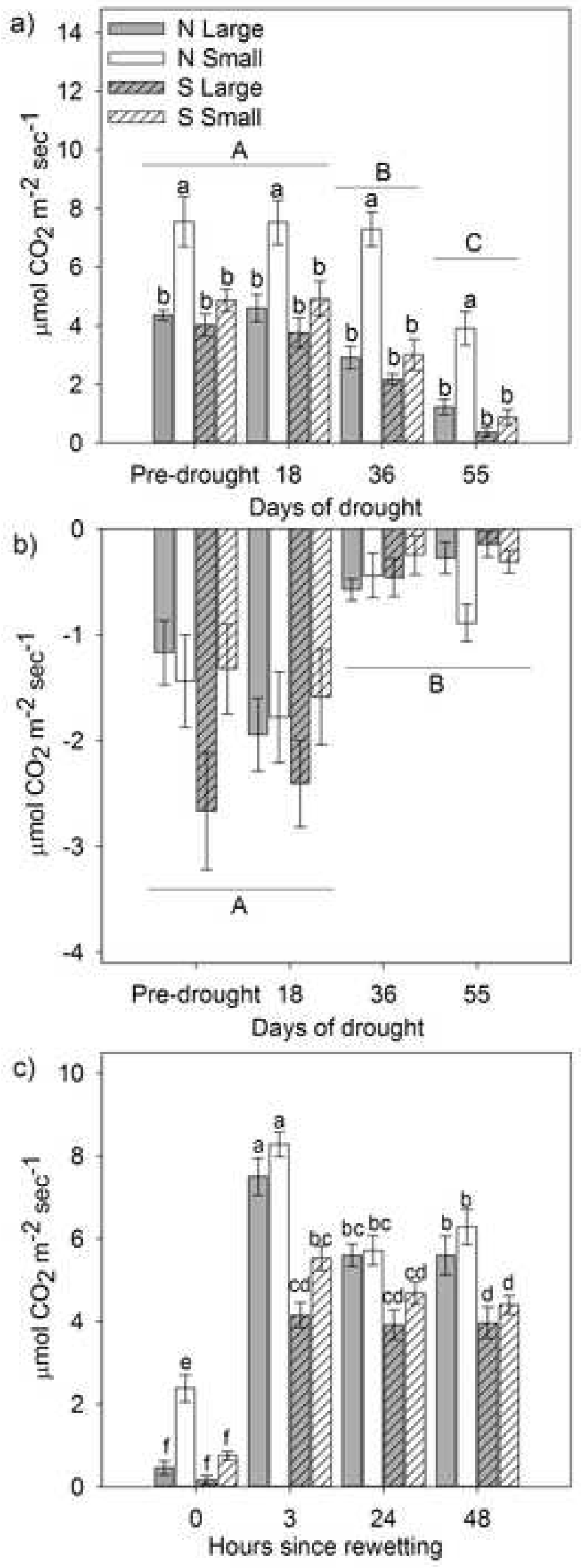


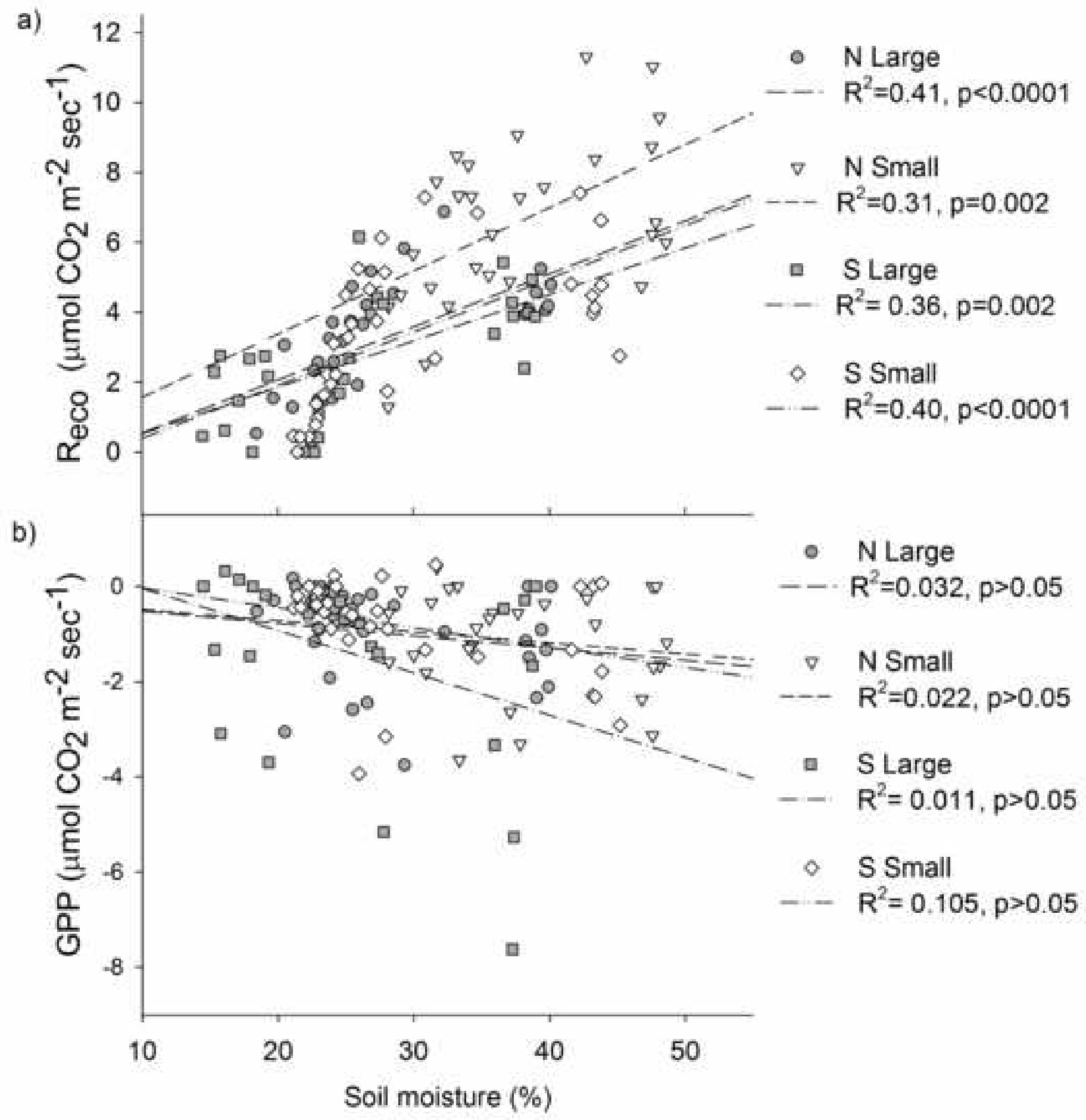



Large fragment
Southern region $\quad \begin{aligned} & \text { Small fragment } \\ & \text { Southern region }\end{aligned} \nabla \begin{aligned} & \text { Large fragment } \\ & \text { Northern region }\end{aligned} \quad \begin{aligned} & \text { Small fragment } \\ & \text { Northern region }\end{aligned}$

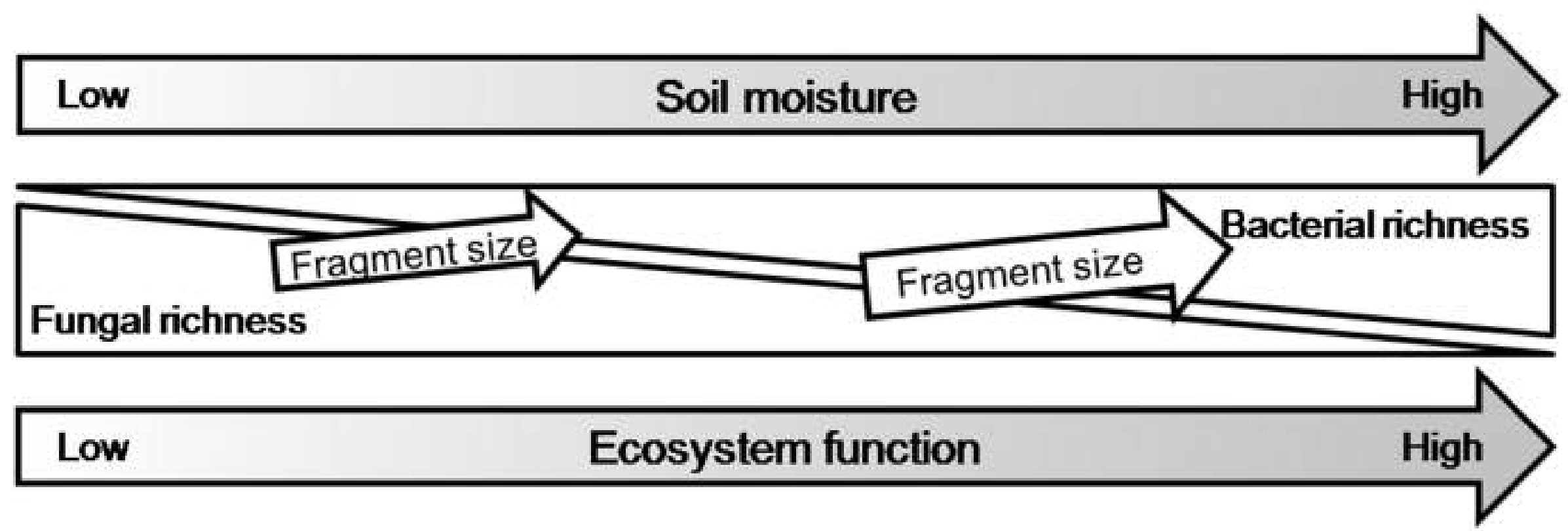


Table 1. Physicochemical characteristics of soils from two climatically different regions and two fragment sizes of Holm oak forest in Spain. Data $=$ mean $(\mathrm{SE})(n=12)$. The effect of factors is summarized on the left of the table. $\mathrm{SOM}=$ soil organic matter; $\mathrm{CEC}=$ cation exchange capacity. Significant differences $(P<0.05)$ between main effects are indicated with capital letters (among region) and lower case letters (among fragment size).

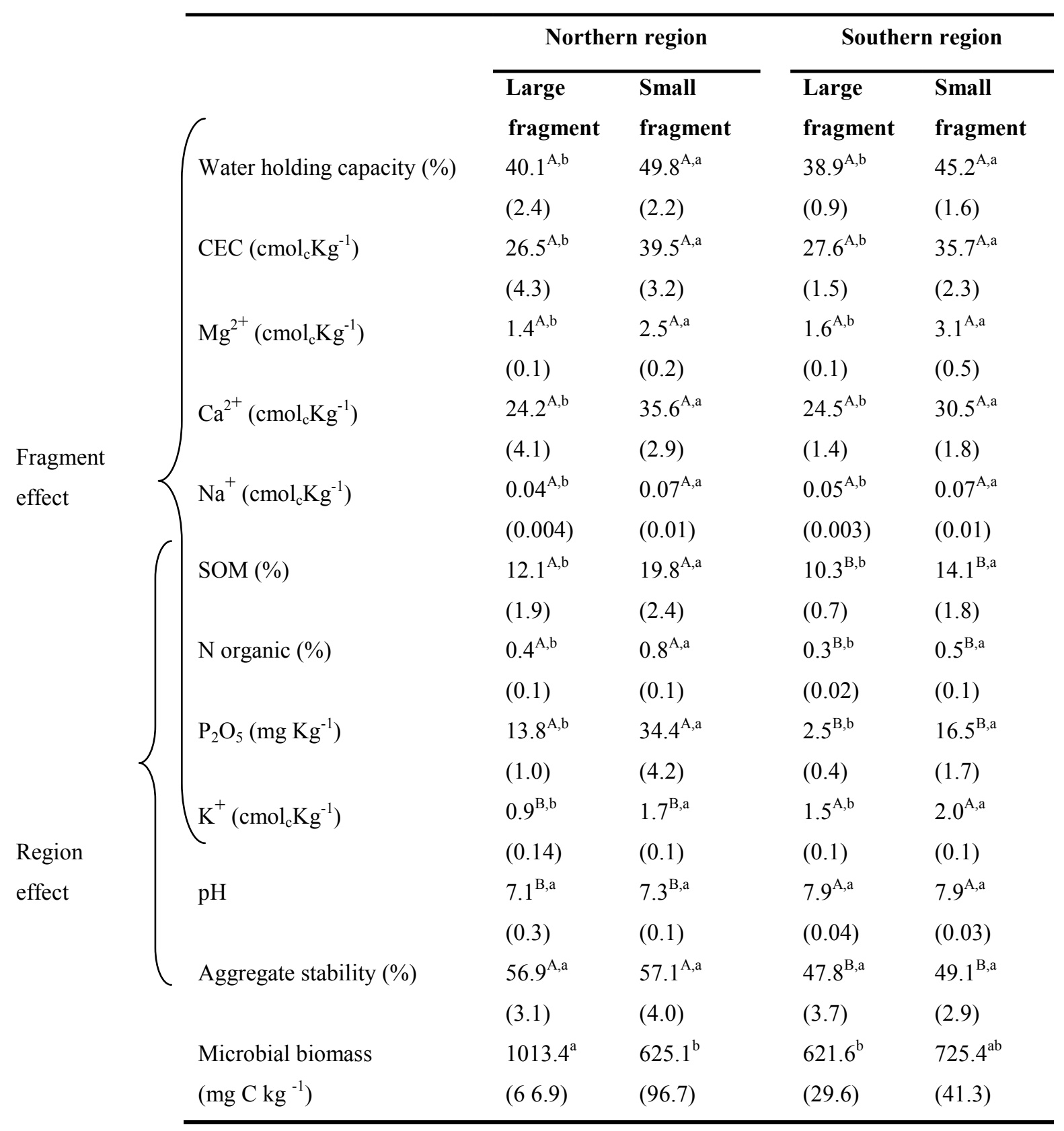


Table 2. Response of fungal and bacterial community composition (first two components of PCA analyses) to the factors region, fragment size and drought at different experimental phases: pre-drought, drought and rewetting simulations, in soils from two climatically different regions and two fragment sizes of Holm oak forest in Spain. Data were analysed by three way ANOVA ( $n=6)$, and significant effects are noted in bold $(*<0.05 ; * *<0.01 ; * * *<0.001)$. PC1 $=$ first component and $\mathrm{PC} 2=$ second component of Principal Component Analysis (PCA). In parentheses: percentage of variation explained by PCA axes.

\begin{tabular}{|c|c|c|c|c|c|c|c|c|c|}
\hline & & \multicolumn{4}{|c|}{ Fungal $(20.5 \%)$} & \multicolumn{4}{|c|}{ Bacterial (33.2\%) } \\
\hline & & \multicolumn{2}{|c|}{ PC1 (11.4\%) } & \multicolumn{2}{|c|}{ PC2 $(9.2 \%)$} & \multicolumn{2}{|c|}{ PC1 (17.4\%) } & \multicolumn{2}{|c|}{ PC2 $(15.8 \%)$} \\
\hline \multirow{8}{*}{$\begin{array}{l}\text { Pre-drought } \\
\text { to Drought }\end{array}$} & & $P$ & $F$ & $P$ & $F$ & $P$ & $F$ & $P$ & $F$ \\
\hline & Drought (D) & $<0.001^{* * *}$ & 63.22 & 0.515 & 0.44 & $<0.001^{* * * *}$ & 539.49 & $<0.0011^{* * * *}$ & 81.852 \\
\hline & Region (R) & 0.155 & 2.23 & 0.070 & 3.77 & 0.421 & 0.685 & 0.296 & 1.173 \\
\hline & Fragment size (F) & 0.280 & 1.25 & $0.030^{*}$ & 5.67 & 0.311 & 1.097 & 0.807 & 0.062 \\
\hline & $\mathbf{D} \times \mathbf{R}$ & $0.001^{* * *}$ & 16.09 & 0.203 & 1.76 & $0.025^{*}$ & 6.178 & 0.188 & 1.902 \\
\hline & $\mathbf{D} \times \mathbf{F}$ & 0.156 & 2.21 & 0.250 & 1.42 & 0.911 & 0.013 & 0.369 & 0.855 \\
\hline & $\mathbf{R} \times \mathbf{F}$ & 0.161 & 2.16 & 0.433 & 0.65 & 0.237 & 1.521 & $<0.0011^{* * * *}$ & 37.134 \\
\hline & $D \times R \times F$ & 0.098 & 3.09 & 0.147 & 2.32 & $0.017^{*}$ & 7.214 & $0.004^{* *}$ & 11.155 \\
\hline \multirow{7}{*}{$\begin{array}{l}\text { Drought to } \\
\text { Rewetting }\end{array}$} & Rewetting (Rw) & $<0.0011^{* * *}$ & 90.87 & $<0.0011^{* * *}$ & 17.05 & $<0.0011^{* * *}$ & 85.59 & $<0.0011^{* * *}$ & 629.044 \\
\hline & Region (R) & $0.007^{* *}$ & 9.73 & 0.686 & 0.17 & $<0.0011^{* * *}$ & 29.08 & 0.053 & 4.405 \\
\hline & Fragment size (F) & $0.034^{*}$ & 5.39 & $<0.0011^{* * *}$ & 23.20 & 0.295 & 1.175 & 0.449 & 0.602 \\
\hline & $\mathbf{R w} \times \mathbf{R}$ & $0.029^{*}$ & 5.78 & 0.054 & 4.32 & 0.398 & 0.758 & $0.002^{* *}$ & 13.269 \\
\hline & $\operatorname{Rw} \times \mathbf{F}$ & 0.150 & 2.29 & 0.129 & 2.55 & 0.625 & 0.249 & 0.729 & 0.123 \\
\hline & $\mathbf{R} \times \mathbf{F}$ & 0.750 & 0.10 & $0.024^{*}$ & 6.24 & $0.024^{*}$ & 6.287 & $0.005^{* * *}$ & 10.833 \\
\hline & $\mathbf{R w} \times \mathbf{R} \times \mathbf{F}$ & 0.761 & 0.09 & 0.589 & 0.30 & $0.012^{*}$ & 8.068 & $0.019^{*}$ & 6.885 \\
\hline
\end{tabular}


Table 3. Seedling growth and physiology during drought simulation in soils from two climatically different regions and two fragment sizes of Holm oak forest in Spain. Data $=$ mean (SE) $(n=7$ for southern large and northern small fragments, and $n=8$ for southern small and northern large fragments). Significant differences $(P<0.05)$ are indicated with capital letters (among region for a given fragment size) and lower case letters (among fragment size for a given region).

\begin{tabular}{|c|c|c|c|c|}
\hline & \multicolumn{2}{|c|}{ Northern region } & \multicolumn{2}{|c|}{ Southern region } \\
\hline & Large fragment & Small fragment & Large fragment & Small fragmen \\
\hline Germination (days) & $64.1(8.2)^{\mathrm{A}, \mathrm{a}}$ & $45.0(3.8)^{\mathrm{A}, \mathrm{a}}$ & $60.6(6.4)^{\mathrm{A}, \mathrm{a}}$ & $53.6(5.9)^{\mathrm{A}, \mathrm{a}}$ \\
\hline Height $(\mathrm{cm})$ & $6.64(0.9)^{\mathrm{A}, \mathrm{a}}$ & $8.6(1.2)^{\mathrm{A}, \mathrm{a}}$ & $8.6(1.9)^{\mathrm{A}, \mathrm{a}}$ & $6.1(0.9)^{\mathrm{A}, \mathrm{a}}$ \\
\hline Diameter (mm) & $2.12(0.2)^{\mathrm{A}, \mathrm{a}}$ & $2.44(0.3)^{\mathrm{A}, \mathrm{a}}$ & $2.3(0.3)^{\mathrm{A}, \mathrm{a}}$ & $2.3(0.4)^{\mathrm{A}, \mathrm{a}}$ \\
\hline Biomass (g) & $1.3(0.3)^{\mathrm{A}, \mathrm{a}}$ & $1.7(0.3)^{\mathrm{A}, \mathrm{a}}$ & $1.4(0.3)^{\mathrm{A}, \mathrm{a}}$ & $1.2(0.4)^{\mathrm{A}, \mathrm{a}}$ \\
\hline Root/shoot ratio & $1.2(0.1)^{\mathrm{A}, \mathrm{a}}$ & $0.9(0.1)^{\mathrm{A}, \mathrm{a}}$ & $1.0(0.2)^{\mathrm{A}, \mathrm{a}}$ & $1.0(0.1)^{\mathrm{A}, \mathrm{a}}$ \\
\hline $\operatorname{SLA}\left(\mathrm{cm}^{2} \mathrm{~g}^{-1}\right)$ & $81.2(3.4)^{\mathrm{B,a}}$ & $71.7(2.3)^{\mathrm{B}, \mathrm{a}}$ & $84.7(3.8)^{\mathrm{A}, \mathrm{a}}$ & $86.2(3.5)^{\mathrm{A}, \mathrm{a}}$ \\
\hline $\mathrm{Fv} / \mathrm{Fm}$ predawn & $0.66(0.09)^{\mathrm{A}, \mathrm{a}}$ & $0.59(0.10)^{\mathrm{A}, \mathrm{a}}$ & $0.63(0.16)^{\mathrm{A}, \mathrm{a}}$ & $0.78(0.04)^{\mathrm{A}, \mathrm{a}}$ \\
\hline Fv/Fm midday & $0.60(0.05)^{\mathrm{A}, \mathrm{a}}$ & $0.51(0.07)^{\mathrm{A}, \mathrm{a}}$ & $0.61(0.03)^{\mathrm{A}, \mathrm{a}}$ & $0.67(0.03)^{\mathrm{A}, \mathrm{a}}$ \\
\hline $\begin{array}{l}\text { Stomatal conductance } \\
\left(\mathrm{mmol} \mathrm{s}^{-1} \mathrm{~m}^{-2}\right)\end{array}$ & $68.3(15.2)^{\mathrm{A}, \mathrm{a}}$ & $74.7(17.8)^{\mathrm{A}, \mathrm{a}}$ & $52(11.2)^{\mathrm{A}, \mathrm{a}}$ & $59.8(13.7)^{\mathrm{A}, \mathrm{a}}$ \\
\hline Water potential (MPa) & $-1.5(0.4)^{\mathrm{A}, \mathrm{a}}$ & $-1.7(0.2)^{\mathrm{A}, \mathrm{a}}$ & $-1.3(0.4)^{\mathrm{A}, \mathrm{a}}$ & $-2.2(1.7)^{\mathrm{A}, \mathrm{a}}$ \\
\hline Survival (\%) & $87.5^{\mathrm{ab}}$ & $100.0^{\mathrm{a}}$ & $57.1^{\mathrm{b}}$ & $87.5^{\mathrm{ab}}$ \\
\hline
\end{tabular}


Table 4. Correlations between soil functioning and soil moisture, fungal and bacterial diversity in soils from two climatically different regions and two fragment sizes of Holm oak forest in Spain. Data were analysed by Pearson's correlation $(n=36)$ and significant effects are noted in bold $(*<0.05$; $* *<0.01 ; * * *<0.001) . \mathrm{R}_{\mathrm{eco}}=$ ecosystem respiration; $\mathrm{PC} 1=$ first component and $\mathrm{PC} 2=$ second component of Principal Component Analysis (PCA). For the full correlation Table see Online Resource 10.

\begin{tabular}{llll}
\hline & $\mathbf{R}_{\text {eco }}$ & Phosphatase & Urease \\
\hline Soil moisture & $\mathbf{0 . 6 8 * * *}$ & $\mathbf{0 . 4 5 * *}$ & $\mathbf{0 . 5 8 * * *}$ \\
Fungal richness & $\mathbf{- 0 . 3 8 *}$ & -0.33 & -0.34 \\
Fungal Shannon index & $\mathbf{- 0 . 3 7 *}$ & $\mathbf{- 0 . 3 8 *}$ & $\mathbf{- 0 . 4 3 *}$ \\
PC1 Fungal & $\mathbf{- 0 . 5 8 * * *}$ & $\mathbf{- 0 . 4 9 * *}$ & -0.30 \\
Bacterial richness & $\mathbf{0 . 4 1 *}$ & $\mathbf{0 . 4 2 *}$ & 0.29 \\
Bacterial Shannon index & $\mathbf{0 . 4 1 *}$ & $\mathbf{0 . 4 0 *}$ & 0.25 \\
PC1 Bacterial & $\mathbf{0 . 4 5 * *}$ & 0.34 & $\mathbf{0 . 5 1 * *}$ \\
PC2 Bacterial & $\mathbf{0 . 3 8 *}$ & -0.10 & 0.06 \\
\hline
\end{tabular}


Table 5. Relationships between fungal and bacterial community structure and explanatory physicochemical soil variables in soils from two climatically different regions and two fragment sizes of Holm oak forest in Spain. Data were analysed by stepwise multiple regression ( $t$-test) and significant effects using corrected $P$-value (sequential Holm-Bonferroni method) are noted in bold $(n=36)$; n.s. not significant. $\beta=$ standardized coefficient. $\mathrm{SOM}=$ soil organic matter. $\mathrm{PC} 1=$ first component of Principal Component Analysis (PCA).

\begin{tabular}{|c|c|c|c|c|c|c|c|c|}
\hline & \multicolumn{4}{|c|}{ Fungi } & \multicolumn{4}{|c|}{ Bacteria } \\
\hline & $\begin{array}{c}\text { PC1 } \\
\left(R^{2}=0.55\right)\end{array}$ & $\begin{array}{l}\text { Richness } \\
\left(R^{2}=0.23\right)\end{array}$ & $\begin{array}{l}\text { Shannon } \\
\left(R^{2}=0.41\right)\end{array}$ & $\begin{array}{l}\text { Evenness } \\
\left(R^{2}=0.39\right)\end{array}$ & $\begin{array}{c}\text { PC1 } \\
\left(R^{2}=0.84\right)\end{array}$ & $\begin{array}{l}\text { Richness } \\
\left(R^{2}=0.37\right)\end{array}$ & $\begin{array}{l}\text { Shannon } \\
\left(R^{2}=0.34\right)\end{array}$ & $\begin{array}{l}\text { Evenness } \\
\left(R^{2}=0.30\right)\end{array}$ \\
\hline \multicolumn{9}{|l|}{ Soil moisture } \\
\hline$\beta$ & -0.79 & -0.35 & -0.52 & -0.51 & 0.98 & 0.33 & 0.23 & -0.52 \\
\hline Pearson correlation & -0.74 & -0.35 & -0.53 & -0.52 & 0.91 & 0.36 & 0.25 & -0.50 \\
\hline$P$ & * & n.s. & $*$ & $*$ & $*$ & n.s. & n.s. & $*$ \\
\hline \multicolumn{9}{|l|}{ pH } \\
\hline$\beta$ & 4.78 & -8.62 & -13.36 & -15.05 & -1.95 & 9.30 & 9.82 & -5.62 \\
\hline Pearson correlation & 0.17 & -0.22 & -0.38 & -0.41 & -0.11 & 0.26 & 0.27 & -0.15 \\
\hline$P$ & n.s. & n.s. & n.s. & $*$ & n.s. & n.s. & n.s. & n.s. \\
\hline \multicolumn{9}{|l|}{ Aggregates (\%) } \\
\hline$\beta$ & 5.35 & -9.88 & -15.21 & -16.95 & -2.26 & 11.11 & 11.68 & -6.37 \\
\hline Pearson correlation & 0.16 & -0.23 & -0.38 & -0.41 & -0.11 & 0.28 & 0.28 & -0.15 \\
\hline$P$ & n.s. & n.s. & n.s. & $*$ & n.s. & n.s. & n.s. & n.s. \\
\hline \multicolumn{9}{|l|}{ SOM (\%) } \\
\hline$\beta$ & -1.14 & 2.40 & 3.80 & 4.39 & 0.15 & -2.89 & -2.93 & 2.04 \\
\hline Pearson correlation & -0.14 & 0.21 & 0.37 & 0.41 & 0.03 & -0.28 & -0.28 & 0.19 \\
\hline$P$ & n.s. & n.s. & $*$ & $*$ & n.s. & n.s. & n.s. & n.s. \\
\hline
\end{tabular}

